\title{
HEALTH EDUCATION: THE ROLE AND FUNCTIONS OF THE SPECIALIST AND THE GENERALIST
}

\author{
Helen P. Cleary*
}

\begin{abstract}
CLEARY, H. P. Health education: the role and functions of the specialist and the generalist. Rev. Saúde públ., S. Paulo, 22:64-72, 1988.

ABSTRACT: Education for health is a process in which all public health and medical care personnel are involved. People learn both formally (planned learning experiences) and informally (unplanned learning experiences). Since the patient, the client, the consummer and the community expect public health and medical care personnel to assist them with health and disease issues and problems, the response of the professional "educates" the customer whether the professional intends to educate or not. Therefore, it is incumbent on all public health and medical care professionals to understand their educational functions and their role in health education. It is also important that the role of the specialist in education be clear. The specialist, as to all other specialists, has an in-depth knowledge of his area of expertise, i.e., the teaching/learning process; $\mathrm{s} / \mathrm{he}$ may function as a consultant to others to enhance the educational potential of their role or $\mathrm{s} / \mathrm{he}$ may work with a team or with communities or groups of patients. Specific competencies and knowledge are required of the health education specialist; and there is a body of learning and social change theory which provides a frame of reference for planning, implementing and evaluating educational programs. Working with others to enhance their potential to learn and to make informed decisions about health/disease issues is the hallmark of the health education specialist.
\end{abstract}

UNITERMS: Health education. Health manpower. Interprofessional relations.

\section{INTRODUCTION}

Education as a viable intervention for the maintenance of health and the prevention of disease has received increasing attention in the last decade. In the United States one factor which has brought education to the fore is the recognition that both individual and collective behavior contribute to the high rate of chronic disease. Behaviors such as overeating, smoking or lack of exercise, all of which have been determined to be major risk factors for cardiovascular disease and cancer, are ameanable to educational interventions.

In public health and medical care, the goal of most of the educational programs is some kind of behavioral change. We look to the elimination of a behavior, such as smoking, or the modification of a behavior, such as dietary practices, or the addition of a new behavior, such as, physical activity.

Many programs with a behavioral change goal, assume that the giving of information about the behavior and its relation to an illness is all that is needed. Information can be useful in the learning process but it is not the total process. If behavior is to be influenced, i.e., people do something different from what they have been doing, additional variables must be considered.

Since education has an excellent potential for the maintenance of health and the prevention of disease and since all health personnel are educators, it is important that there be a common understanding of their educational role versus the role of the health education specialist. It is equally important that all public health and medical care personnel have a grasp of basic learning principles and the application of these principles to their specific setting.

This paper will define education as it applies to health/disease issues and concepts often used synonomously with health education, i.e., learning, social change and compliance. It will describe the educational component of the role of all health professionals, and the difference between that role and the role of the health education specialist. The * Family \& Community Medicine. University of Massachusetts Medical School. Worcester, Massachusetts
01655. 
knowledge and skills required of the health education specialist role, the process by which that role was developed and the working relationship between other health professionals and the health education specialist will be detailed. Finally theories and learning principles basic to the practice of health education will be set forth.

\section{DEFINITIONS}

\section{Health Education}

Health education as applied to health and disease issues is defined as "A process with intellectual, psychological, and social dimensions relating to activities which increase the abilities of people to make informed decisions affecting their personal, family, and community well being. This process, based on scientific principles facilitates learning and behavioral change in both health personnel and consumers, including children and youth," (Joint Committee ${ }^{8}, 1973$ ).

\section{Learning and Social Change}

There is sometimes confusion about the difference between "learning" and "social change". That is understandable since the experts have difficulty defining either term precisely. The fact is these concepts are two sides of the same coin.

\section{Learning}

Kidd $^{10}(1977: 24,15,16)$ suggests that although "we cannot pin down anything as dynamic as learning... we can observe it, note its course and its character. . . Learning... is not simply a matter of accretion - of adding something.... Learning involves a change in behavior: [it] may make us respond differently... These [responses] may be primarily intelectual changes - the acquiring of new ideas or some reorganization of presently held ideas. The changes may be in attitude where we hope that people will come to a different appreciation and more positive feelings about a subject. . Or they may be changes in skill where we expect the learner to become more efficient in performing certain acts... Much of learning is related to shifts in the tasks or roles that a person performs." Other educators agree with Kidd's description (Darkenwald and Merriam ${ }^{5}$ 1982:8; Knowles ${ }^{11}$ 1970:50-52).

From this definition, the reader will recognize that "learning" occurs within the individual; whereas education is of ten defined as teaching the learner or the process of helping the learner, learn. However, some definitions of education include both teaching and learning.

\section{Social Change}

Zaltman and Duncan ${ }^{27}(1977: 6,9)$ state that "perhaps the most difficult conceptual issue in studying social chance is to adequately define social change. There is a wide array of theories focusing on the process of social change, leaving the definition implicit in the theory." Further, persons or groups change their behavior "when they define the situation as being different and now requiring different behavior." Rogers ${ }^{20}$ (1983) describes social change as "the process by which alterations occur in the structure and function of a social system... The structure of a social system is provided by the various individual and group statuses which compose it. The functioning element within this structure of status is a role, or the actual behavior of the individual in a given status."

Although both processes, learning and social change, require individual change, they differ significantly in their central focus: learning tends to focus on change as it relates to the individual; social change tends to focus on change as it occurs in groups or social systems or society. There are, however, social change theories about individual change (Weber $^{26}, 1958$ ). Both perspectives recognize that individual learning can result in societal change, and that societal change does require that a certain number of individuals have learned. The similarity between these two concepts is clear. It is also obvious that, in regard to health education activities, in the community setting it is often more appropriate to use social change principles rather than learning principles, whereas in a school or medical care setting, learning principles are apt to be more useful than social change principles.

\section{Compliance}

The term "compliance" is used in medical care settings to describe a patient's adherence e or leack of adherence to a medical regimen. It is often used in public health circles to describe a community's adherence to certain regulations. Compliance and learning are different concepts. They represent essentially different processes which can be, but are not necessarily related.

Although Haynes et al. ${ }^{7}$ (1979) have written a valuable literature review on compliance, 
nothing in the literature links the compliance process with the learning/change process. Lewin $^{12}$ (1951:77-81) provides us with an explanation of this relationship. He speaks of "imposed" learning and "learned" learning. Imposed learning is applied to those individuals who either are not interested in change or are learning against their will. Kelman (1958) calls this process "forced compliance". People can be forced to comply if they feel that the reward or punishment is great enough, that the proposed action is the lesser of two evils, that they face legal constraints, or that they are not totally aware of the end result of the involvement.

Compliance is sometimes the only course by which people can be helped to alter their behavior in order to protect the public health or welfare or to defend human dignity. If the time bought by compliance helps people learn the relevance of a new behavior to their goals, it may lead to the acceptance of the new behavior. Adoption of a practice, therefore, does not necessarily mean that individuals have learned. It may mean they are complying merely because they have no other choice.

Lewin's "learned" learning refers to the process that occurs when someone decides he or she wants to learn/change. An individual changes because the new behavior is seen as consonant with personal goals, it is identified with a person or thing that he or she admires and wishes to imitate, or the locus of the behavior changes so that the meaning of the behavior takes on a new significance.

\section{Educational Role of Health Professionals}

Public health and medical care professionals will identify with these definitions. For example, with regard to the definition of health education, the nutritionist, environmentalist, physician, nurse, physical therapist, do "increase the abilities of people to make informed decisions affecting their personal, family and community well being." Education is clearly integral do the role of all health professionals. In fact the providers of public health and medical care are usually the first line educators of the patient, the consumer, the community.

Role theory holds that the occupation of a position in a social system is a role that carries with it expectations from those who interact with it (Merton $\left.{ }^{14}, 1957\right)$. Thus patients and consumer have expectations of doctors, nurses, dietitians, environmentalists, physical therapists, and other providers of public health and medical care. One of these expectations is that the provider will help them learn to cope with their illness or their community health problem. The provider fulfills this expectation either positively or negatively in every encounter with a patient, or community by what is said and done and by what is unsaid and not done. There is no way a provider can avoid this expectation.

The second theory that supports this perspective is the concept of informal learning (Hall ${ }^{6}$, 1973). Informal learning, commonly referred to as modeling, is a major concept of Bandura's ${ }^{2}$ (1977) social learning theory. Modeling, or social learning, means that individuals and communities learn from their environment through what they see being done, what they hear, and what they feel. The application of informal learning to the provider's role in public health and medical care is clear. Learning occurs during the patient/ doctor interaction - that is, history taking, physical examination, and the diagnostic process. Learning occurs during the provider/ community interaction - that is, analysis and discussion of a community health problem, development of a plan to deal with the problem implementation of the plan.

The physician, the nurse, and other providers tell the patient whether they care and give the patient clues about the seriousness of the condition through their body language and what they do or do not say to the patient (Redman $^{19}$, 1976:10). The community health worker, whether nurse, physician or environmentalist, tell the community whether they are genuinely concerned about the health problem and give the community clues about their willingness and capability to help with it by their behavior.

The expectations attached to the role of providers of public health and medical care and the fact that learning occurs informally will not change. Education, therefore, cannot be considered an appendage to public health and medical care; it is an integral part of both.

The two major differences between the educational function of the providers of public health and medical care and the functions of a health education specialist is their role identification and job responsibilities. The physician's primary professional identity is in the area of medicine, the nurses is nursing, and the dietitian's is nutrition, and the health 
educator's is in the area of education. The primary responsibility of physicians, nurses, and others in a medical care setting (a hospital or ambulatory center) is to provide medical care for the patient. In carrying out their specific patient-care role, they are all responsible for educating the patients with whom they come in contact. In a public health setting the physician or nurse may work directly with individual patients in the clinic or they may work with groups of consumers or with the community leadership in assessing public health problems, and ways in which the community and the public health personnel can work together to alleviate or eliminate the problems.

In contrast the primary responsibility of the health education specialist in a hospital or other medical care setting is the overall planning, implementation and evaluation of education programs for a variety of patient needs. In a public health setting, the role is similar, that is, the overall planning and implementation of the educational component of the public health programs. A second responsibility in both settings is to function as a consultant to other medical care and public health personnel relative to their use of education. The health educator can help other health professionals enhance and maximize the educational potential of their role. This function is analogous to consultation offered the family physician by the cardiologist - or consultation offered the classroom teacher by the reading expert.

\section{Health Education Specialist}

Allegrante $^{1}$ (1986) has expressed the uniqueness of education in the health field in this way:

"The goal of health education is to promote, maintain, and improve individual and community health through the educational process. The conceptual hallmarks and social agenda that differentiate the practice of health education from that of other helping professions in achieving this goal include: (1) using consensus to identify health needs and problems; (2) voluntariness of participation as an ethical requirement; and (3) a focus on stimulating social and organizational behavior change in defined populations. Like the other helping professions, our methodologies also require that we enter into a social contract in dealing with people; however, it is the emphasis on the teaching - learning process the inherent belief in the individual's capacity to learn and assume responsibility - that comprises the raison d'etre of health education and which sets it apart from the other fields. Health education is eminently interested in giving people the empowered role of defining their problems, setting the priorities, and creating the practical solutions by which they achieve a sense of interest in, commitment to, and ownership over the efforts used to address health issues."

"The nature of work in health education is thus respectful of the individual as an actively involved learner, a full partner in the change process who is a rational, purposeful person capable of acting on and responding to one's environment in the best tradition of Dewey's, Bruner's, Freire's, and Bandura's notions of self-determinism. While the frame of reference in health education is that of health, the principles, processes and habits of mind are essentially those derived from the equalitarian spirit and progressive theories of education and the fundamental theories of the behavioral sciences." (Allegrante ${ }^{1}, 1986$ ).

Therefore, the distinguishing characteristic of the health education specialist is understanding and skill in applying the teaching/learning process to health and disease issues. In 1978, a group of health educators in the United States saw the need for a definition of the specific responsibilities and competencies required of the health education specialist to implement the teaching/learning process (US Public Health Service ${ }^{24}, 1978$ ). In other words, what specifically does a health educator do.

The first step in dealing with this need was an agreement that there were a sufficient number of commonalities in the practice of health education in all settings to call all health educators members of one profession regardless of whether they taugh or coordinated health education in the schools, developed health education programs in medical care institutions, communities or worksites (US Public Health Service ${ }^{24}$, 1978). The second step was the definition of the role of the health educator. Seven responsibilities and related competencies and sub-competencies were identified by a committee of experts. The responsibilities and related competencies were defined in terms of what individual health educators should be able to do; not what they knew, but the skills or competencies they had (US Public Health Service ${ }^{25}, 1980$ ).

A second committee of experts developed a process for verifying this definition of the 
role in which several steps were taken. One was a survey of practicing health educators working in schools, community, medical care and worksite settings, in which they were asked whether they did the things the experts said they did, and if they did, how important were these to them on a day-to-day basis. The data from this survey indicated that all health educators in all settings used all seven responsibilities and related competencies. The difference among settings was one of emphasis. In some settings some competencies were used more often than another (US Department Commerce ${ }^{23}$, 1982). Following the survey, there was a series of workshops for faculty preparing health educators who provided feedback on the defined role from their perspective. The defined role was also discussed at professional meetings for two years.

As a result of the verification process, the initial definition of the role was simplified since it was considered too complex for entrylevel. The seven responsibilities, 27 competencies and 77 sub-competencies, were retained, but the language was simplified. Based on the verified role, a curriculum framework was developed as a guide for institutions preparing health educators (NTFPPHE, 1985). The verified role is also the basis for selfassessment instruments and a continuing education model to assist practitioners in identifying their skills (NTFPPHE ${ }^{17}, 1987$ ).

The final step in this process is the development of a credentialing or accountability system. This will include a series of examinations required for acceptance as a certified health education specialist. That step is in process at this time.

The responsibilities and competencies of the health education specialists as currently defined operationalize learning principles. They are for the entry-level health educator and they are generic, that is, they apply to the practice of health education in all settings. At the advanced level, the health education specialist carries out the same responsibilities but at a greater degree of complexity. And, at that level, additional competencies in management and research are needed.

Valuable as these competencies are in defining the role of the health educator, they constitute only one component of the foundation of this profession. Knowledge of current health/disease issues and of the epidemiology of current health topics, biostatistics, learning theory, a philosophical framework and a va- riety of strategies and methods useful in the practice of health education, are equally essential.

In addition, professional operating procedures such as building relationships and developing credibility are as essential to carrying out daily activities as knowledge and skills. Finally, one needs practice management techniques to facilitate the accomplishment of tasks; for example, an appropriate filing system, and a system for communication with administration.

Figure illustrates the linkage between the component parts of the day-to-day activity of a health education specialist.

\section{Relationship Between Health Education Specialist and Other Health Professionals}

The responsibilities, skills and knowledge required of the health education specialist, described above, can be carried out in many different ways depending on the setting and the needs of the institution, consumers or community. The education specialist may function as a consultant to other health professionals or to a community. For example, $\mathrm{s} /$ he may work with public health nurses in setting up an educational program in a clinic for mothers and infants; or with physicians and nurses in a cardiac care unit developing materials for patients' families. Or $s /$ he may function as a member of a public health or medical care team in a hospital or clinic. For example, a team for educating diabetic patients could include a physician, nurse, dietitician and a health educator; or a public health team concerned with pollution of a river could include an environmentalist, a toxicologist, a public health physician and a health educator. Or the health educator may be the only health professional working with a community to help the community understand the need for draining small pools of stagnant water, and devise a plan with the ocmmunity for doing so.

As the definition of health education suggests, the primary role of the health education specialist is to facilitate the learning process and help the individual or community to make informed decisions about health/ disease issues. The health educator, therefore, never works alone but always together with individuals, groups or communities to assist them in dealing with health/disease issues and to facilitate their learning. 


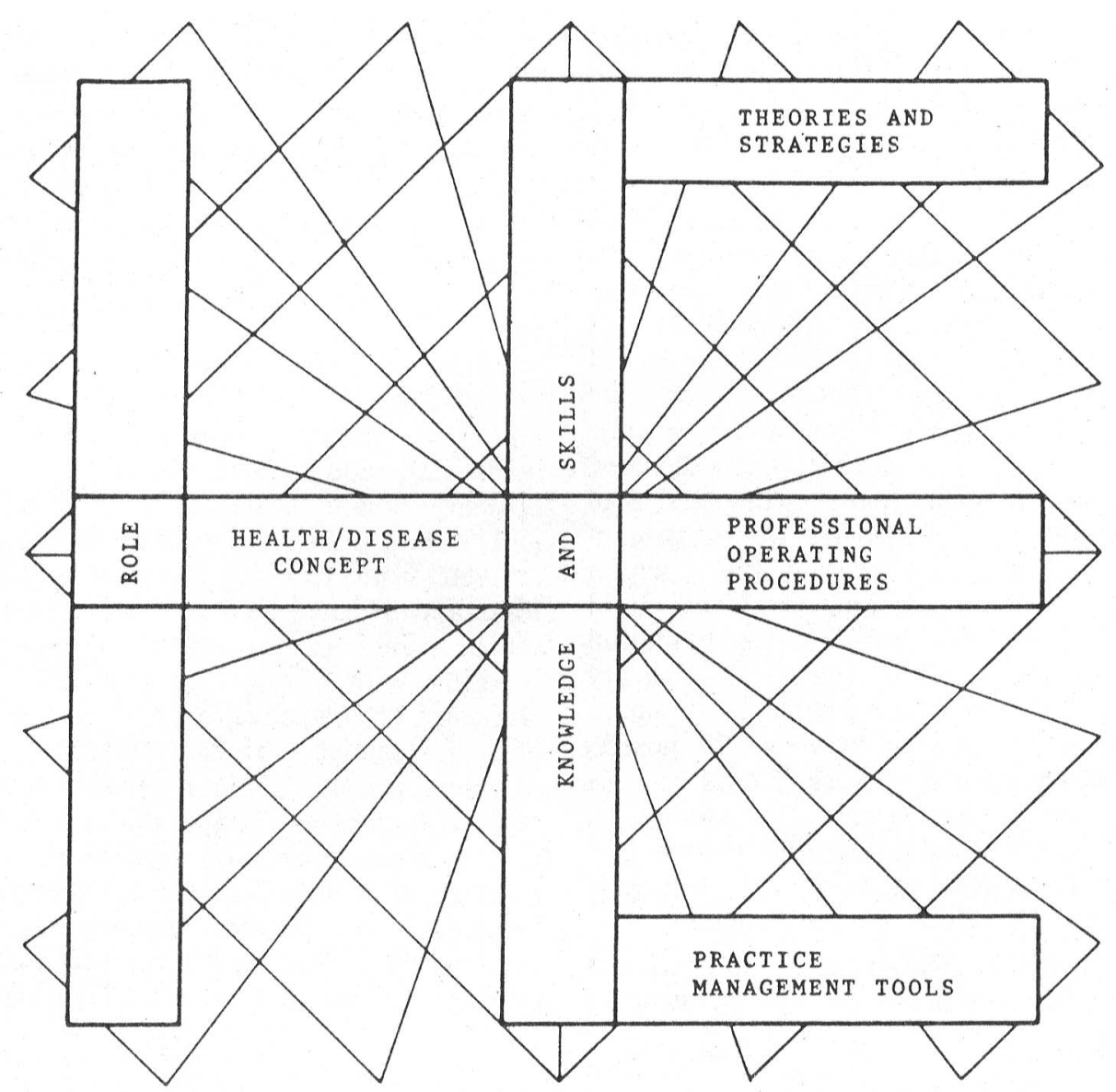

Fig. Practice of health education.

Source: Cleary, H. P. et al. ${ }^{4}$

\section{Theory}

All professions require a comprehensive statement of essential theory recognized by the individual practitioner as their base of operation. Health education does not have a theoretical base separate and distinct from other professions that deal with human services. It is drawn from education and the social and behavioral sciences. All human service professions operate on a similar theoretical base because they all deal with human behavior. Many of their social, behavioral, and educational theories have been derived from observations and maxims of human behavior that were described by ancient masters, that is, the biblical writers and the Greek and Roman philosophers (Ulich ${ }^{22}, 1971$ ). Each of the professions has adapted, refined, and expanded these descriptions and formulated principles based on the language of its own specialty.

Because health education draws its theoretical base from education and the social and behavioral sciences, a large resource of developed theory is already available to the health educator. To eliminate potential confusion, it is important to remember three facts about theory development.

1. Theories relevant to the practice of health education deal with human behavior (individual, group, and organizational) and with ways that people learn/change.

2. Theories are formulated from different perspectives; for example; psychologists look at individuals, sociologists look at communities, and anthropologists look at cultures.

3. Theories formulated by the various branches of education and the behavioral and social sciences often deal with identical or similar concepts at different levels of abstraction.

Theories can be applied to either a specific or a broad-based area. Mullen's ${ }^{15}$ (1978) work, 
which explains the specific responses of postmyocardial infarction patients to their disease, is an example of a specific application, and Roger's explanation of the phenomenon of adoption-diffusion concepts covers a wide spectrum.

Learning theories, espoused by educational psychologists, and social change theories defined by sociologists are useful in establishing explanation and prediction of human behavior. Kidd $^{10}$ (1977) has identified theories of learning stated by psychologists. The three classes of theories most useful in the practice of health education are cognitive theories, field theories and social learning theories. Bruner's ${ }^{3}$ (1966) theory of instruction, his concepts of the process of education, his views on curriculum development, and his ideas about readiness to learn offer guides and explanation for practitioners. Lewin's ${ }^{12}$ (1951) field theory of learning, including the concepts of life space and "learned" learning versus "imposed" learning (discussed above), offers explanations and guides for the health education specialists. Bandura's ${ }^{2}$ (1977) social learning theory formalizes the concept of modeling, long recognized as a way by which people learn.

The sociological theory of social change most useful in the practice of health education is that of adoption-diffusion (Rogers ${ }^{20}, 1983$ ). As Martindale ${ }^{12}$ (1972:18) points out, social action theorists have not generated a wellformulated theory of social change but have "produced a large number of generalizations usually employed by sociology at present to account for various special changes without anchoring these ideas in a single identifiable theory of social change."

In addition to these theories that have been drawn from the behavioral and social sciences and have proven useful in the practice of health education, there are several principles of learning and social change. Taba ${ }^{21}$ (1962) and others identified principles of learning derived from well-developed learning theory. Pine and Horne ${ }^{18}$ (1969) identified a similar set of principles through their experience in working with antipoverty aids. Zaltman and Duncan $^{27}$ (1977) developed a set of principles of social change derived from the experiences of many people. Table I presents a synthesis of learning/social change principles, found in the literature, which are directly related to the practice of health education. These principles are as relevant to the educational component of the role of the health professional as they are for the health educational specialist.

TABLE 1

Syntesis of learning/social change principles directly related to the practice of health education.

1. People learn and people change as a result of informal as well formal processes.

2. People learn and people change as the result of a number of different experiences.

3. People will learn about or will change those things they perceive to be meaningful and useful to them.

4. People will learn or change those things acceptable to their social group.

5. People will learn or change those things they have an opportunity to explore.
6. Learning and change have an affective as well as a cognitive component.

7. Involve the learners or those who are to change in the process of learning or changing.

8. Begin where the learner or the target population is.

9. People learn and people change over time; learning and change take time.
Mullen et al. ${ }^{16}(1985)$ expressed similar principles in different terms (Table 2). The difference in the terminology does not mean that the basic concepts are different. Mullen's choice of learning principles was dictated by setting and program. She was discussing education of patients in hospitals about taking medication; for the most part, this was oneto-one education, and nurses were the edu- cators. The learning principles expressed in Table 1 provide a good fit for a community setting. It is critical that those involved in educating patients or the public about health/ disease not be confused by terminology but rather look beyond the words to the meaning. There are many different ways to express similar concepts; what is important is to grasp the meaning of the concept regardless of the words used to express it. 
TABLE 2

Learning Principles (adapted from Mullen 1985)

1. Relevance. The tailoring of the program to knowledge, beliefs, circumstances, and prior experience of the learner, as assessed by pretesting or other means.

2. Individualization. The provision of opportunities for learners to have personal questions answered or instruction paced according to their individual progress. Methods that allow for individualization include programmed learning, individual counseling "exit interviews," and discussion periods during group sessions or lectures.

3. Feedback. Information given to the learner regarding the extent to which learning is being accomplished. This could include clinical data regarding the control of the disease, e.g., blood pressure reading.
4. Reinforcement. Any component of the intervention that is designed to reward the behavior (other than feedback) after the behavior has been enacted. This category also includes statements of support and encouragement, and it excludes informational statements.

5. Facilitation. The provision of means for the learner to take action and/or means to reduce barriers to action. This includes unit dose containers and calendars; adjustment of the regimen to suit the patient's mealtimes, employment, and/or other personal schedules; and provision of free medication or subsidy where cost is a barrier.

CLEARY, H. P. Educação em saúde: papel e funções do especialista e do generalista. Rev. Saúde públ., S. Paulo, 22:64-72, 1988.

RESUMO: A Educação em Saúde é um processo no qual todo o pessoal da saúde pública e do atendimento médico estão envolvidos. As pessoas aprendem ou formalmente (experiências de aprendizagem planejadas) ou informalmente (experiências de aprendizagem não planejadas). $\mathrm{Na}$ medida em que o paciente, o cliente, o usuário - a comunidade esperam que o pessoal da saúde pública e o pessoal do atendimento médico os auxiliem, no que diz respeito a assuntos e a problemas da saúde, a resposta do profissional "educa" o usuário, quer o profissional tenha ou não tenha a intenção de o fazer. Portanto, cabe a todos os profissionais da saúde pública e do atendimento médico entender suas funções educativas e seu papel na Educação em Saúde. E também importante que o papel do especialista em educação esteja claro. O especialista, tanto quanto os outros especialistas, possui um profundo conhecimento na sua área técnica como, por exemplo, o processo de ensino-aprendizagem; pode trabalhar como um consultor para ampliar o potencial educativo de outros ou pode trabalhar com equipes, com comunidades ou com grupos de pacientes. É preciso que o especialista em Educação em Saúde tenha conhecimentos e competências específicos e há um conjunto de teorias de aprendizagem e de mudança social que proporcionam um esquema de referência para planejar, implementar e avaliar programas educativos. Trabalhar com pessoas para ampliar seu potencial quanto à aprendizagem e a tomar decisões informadas a respeito de assuntos relacionados à saúde/doença é o objetivo do especialista em Educação em Saúde. fissionais.

UNITERMOS: Educação em Saúde. Recursos humanos em saúde. Relações interpro-

\section{REFERENCES}

1. ALLEGRANTE, J. Preface. In: National Task Force on the Preparation and Practice of Health Educators. Framework of the development of competency-based curricula for entry-level health educators. New York, NY, 1986. p. 5-9.

2. BANDURA, A. Social learning theory. Englewood Cliffs, NJ, Prentice Hall, 1977.

3. BRUNER, J. S. Toward a theory of instruction. Cambridge, Harvard University Press, 1966.
4. CLEARY, H. P.; KICHEN, J. M.; ENSOR, P. G. Advancing health through education: a case study approach. Palo Alto, Ca., Mayfield, 1985 .

5. DARKENWALD, J. J. \& MERRIAM, S. B. Adult education foundations of practice. New York, Harper \& Row, 1982.

6. HALL, E. T. The silent language. Garden City, NJ, Doubelday (Anchor Books), 1973. 
7. HAYNES, R. B.; TAYLOR, D. W.; SACKET, D. I. Compliance in health care. Baltimore, Johns Hopkins University Press, 1979.

8. JOINT COMMITTEE ON HEALTH EDUCATION TERMINOLOGY. New definitions: report of the 1972-1973. Hlth Educ. Monogr., (33):63-70, 1973.

9. KELMAN, H. C. Compliance, identification and internalization: three processes of attitude change. J. Conflict Resolution, 2:1-60, 1958.

10. KIDD, J. R. How adults learn. New York, Association Press, 1977.

11. KNOWLES, M. The modern practice of adult education. New York, Association Press, 1970 .

12. LEWIN, K. Field theory in social science. New York, Harper, 1951.

13. MARTINDALE, D. Perspectives on the process of social change. In: Zaltman, G.; Kolte, P. \& Kalfman, I., ed. Creating social change, Holt, Rinehart and Windston, 1972.

14. MERTON, R. K. Social theory \& social structure. Glencoe, Ill., Free Press, 1957.

15. MULLEN, P. D. Cutting back after a heart attack. Hlth Educ. Monogr., 6:295-311, 1978.

16. MUlleN, P. D.; GREEN, L. W.; PERSINGER, G. S. Clinical trials of patient education for chronic conditions: a comparative meta-analysis of intervention types. Prev. Med., 14: 753-81, 1985.

17. NATIONAL TASK FORCE ON THE PREPARATION AND PRACTICE OF HEALTH EDUCATORS (NTFPPHE). Continuing pro- fessional development for health educators. New York, NY, 1987.

18. PINE, G. J. \& HORNE, P. J. Principles and conditions for learning in adult education. Adult Leadership, 18:108-34, 1969.

19. REDMAN, B. K. The process of patient teaching in nursing. St. Louis. Mosby, 1976.

20. ROGERS, E. M. Diffusion of innovation. 3rd. ed., New York, Free Pres, 1983.

21. TABA, H. Curriculum development: theory and practice. New York, Harcourt, Brace, Jovanovich, 1962.

22. ULICH, R., ed. Three thousand years of edlcational wisdom. Cambridge, Harvard University Press, 1971.

23. U. S. DEPARTAMENT OF COMMERCE. The refined and verified role for entry-level health educators. Washington, D. C., 1982. (HRP-09-04273).

24. U. S. PUBLIC HEALTH SCIENCE. Preparation and practice of community, patient and school health educators. Washington, D. C., 1978. (DHEW Publication n. (HRA) 78-71).

25. U. S. PUBLIC HEALTH SCIENCE. Initial role delineation for health education. Washington, D. C., 1980. (DHHS Publication n. ${ }^{\circ}$ (HRA) 80-84).

26. WEBER, M. The protestant effort and the spirit of capitalism. New York, Scribner, 1958.

27. ZALTMAN, G. \& DUNCAN, R. Strategies for planned change. New York, Wiley, 1977.

Received for publication: 16/7/1987 Accepted for publication: 14/10/1987 